\title{
ADAM HABUDA, OBSZARY NATURA 2000 W PRAWIE POLSKIM, WYDAWNICTWO DIFIN SA., WARSZAWA 2013 (RECENZJA)
}

\section{ADAM HABUDA, OBSZARY NATURA 2000 W PRAWIE POLSKIM [NATURA 2000 AREAS IN THE POLISH LAW], DIFIN SA., WARSAW 2013 (REVIEW)}

\section{Słowa kluczowe}

Forma ochrony przyrody; Natura 2000; prawo Unii Europejskiej.

Keywords

Methods for nature conservation; Natura 2000; European Union Law.

" Dr hab., Instytut Nauk Prawnych PAN. 
Recenzowana praca, licząca 270 stron, jest pierwszym w polskim piśmiennictwie prawniczym opracowaniem monograficznym poświęconym obszarom Natura 2000. Podjęcie tej problematyki zasługuje na pełną aprobatę, gdyż wiąże się z nią wyjątkowy potencjał konfliktów. Nie jest tajemnicą, że europejskie prawo ochrony przyrody napotyka na silną krytykę. Głoszone są między innymi opinie, że jego wykładnia i stosowanie wstrzymuje (głównie za sprawą orzecznictwa Europejskiego Trybunału Sprawiedliwości) racjonalny rozwój infrastruktury oraz przyczynia się do faktycznej utraty kompetencji przez organy państwa na rzecz organizacji społecznych. Wyrażane są też wątpliwości co do sposobu pojmowania działań zapobiegawczych i kompensacyjnych, zwłaszcza w kontekście zasady proporcjonalności. Nierzadko milionowe nakłady prowadzą bowiem do uzyskania wątpliwych efektów a to dyskredytuje w oczach opinii publicznej ochronę przyrody. Przypomnieć można, jakim - bez mała wstrząsem - była inicjatywa premiera Holandii Balkenende, który zwrócił się z wnioskiem do Przewodniczącego KE M. Barroso, aby poluzować reżim dyrektywy ptasiej i siedliskowej (pomysł został zdecydowanie odrzucony).

Praca składa się z wprowadzenia, pięciu poprawnie usystematyzowanych rozdziałów oraz zakończenia, których układ oddaje tok badań, wynikający z analizy konstrukcji prawnej obszaru Natura 2000, przyjętej przez Autora jako oś narracyjna.

W rozdziale pierwszym Autor przedstawia najpierw miejsce, jakie zajmuje prawo ochrony przyrody w systemie prawa ochrony środowiska, a następnie koncepcję legislacyjną ochrony przyrody i na tym tle szczegółowo omawia prawną pozycję obszaru Natura 2000 w relacji do innych form ochrony przyrody. Obszerne wywody kończy konkluzja pewnej relatywności w ocenie restrykcyjności reżimu prawnego obszarów natura 2000, zwłaszcza w porównaniu do innych tradycyjnych form ochrony przyrody.

Przedmiotem rozdziału drugiego jest proces wyznaczania obszaru Natura 2000. Rozdział ten otwiera punkt „Organ ochrony przyrody na tle ogólnej teorii organu administracji publicznej", ujęty chyba nieco zbyt szeroko. Następnie Autor przybliża źródła rozwiązań proceduralnych, omawiając kolej- 
no przepisy dyrektywy w sprawie ochrony dzikiego ptactwa, dyrektywy w sprawie ochrony siedlisk naturalnych oraz dzikiej fauny i flory i w końcu polskiej ustawy o ochronie przyrody. $\mathrm{W}$ kolejnym fragmencie przechodzi do jednej $\mathrm{z}$ najistotniejszych części monografii, czyli analizy form prawnych działań podejmowanych przy wyznaczaniu obszaru natura 2000. Kolejno ocenia charakter prawny: 1) projektu listy obszarów Natura 2000 opracowywanego przez Generalnego Dyrektora Ochrony Środowiska, 2) opiniujących uchwał rad gmin, 3) zgody Rady Ministrów na kształt listy przedstawionej przez Ministra Środowiska, 4) projektu wykazu terenów mających znaczenie dla Wspólnoty, opartego na wykazie państwa członkowskiego, opracowanego przez Komisję w porozumieniu z państwem członkowskim, 5) decyzji KE zatwierdzającej wykaz terenów mających znaczenie dla Wspólnoty, kończąc na 6) rozporządzeniu Ministra Środowiska, wyznaczającym obszar specjalnej ochrony ptaków lub specjalny obszar ochrony siedlisk. Rozdział drugi zamykają uwagi o konsekwencjach prawnych wyznaczenia obszaru Natura 2000. Autor wskazuje m.in. na konsekwencje dotykające właścicieli nieruchomości znajdujących się w granicach obszaru Natura 2000.

Rozdział trzeci zatytułowany „Zarządzanie obszarami Natura 2000" poświęcony został reżimowi prawnemu takich obszarów. Akcentowane w tytule „zarządzanie” oznacza dla Autora ciąg działań w postaci planowania, decydowania i kontrolowania przy pomocy rozbudowanych instrumentów, które współtworzą reżim obszaru. W tym też dostrzega podstawową różnicę $\mathrm{w}$ stosunku do tradycyjnych form ochrony przyrody, które zdominowane są przez zakazy. Co więcej, zarządzanie to ma dla Niego nie tylko wymiar operacyjny, ale też znamiona zarządzania strategicznego, opartego na długim horyzoncie czasowym. Ponadto wyróżnia europejski wymiar zarządzania (zarządzanie całą siecią) oraz jednostkowy (dotyczący każdego obszaru z osobna). Omawiając tak zdefiniowany system, przedstawia podmioty zarządzające obszarami (w konsekwencji nie tylko krajowe, ale i europejskie), następnie instrumenty planistyczne oraz na koniec nadzorcze. Najbardziej rozbudowana merytorycznie jest część poświęcona planom zadań ochronnych 
oraz planom ochrony (s. 79-104). Rozdział ten kończy omówienie skutków prawnych oceny oddziaływania na obszar Natura 2000, przedstawione przez pryzmat form działania organów unijnych i krajowych.

Obszerny jest także ostatni rozdział piąty, w którym podjęte zostały kwestie odpowiedzialności prawnej za naruszenie reżimu prawnego obszaru Natura 2000. Autor odwołuje się do klasycznych postaci odpowiedzialności prawnej, a mianowicie odpowiedzialności administracyjnej, odpowiedzialności karnej i odpowiedzialności cywilnej. Odrębny punkt poświęcony został nowym (co najmniej w sensie chronologicznym) formom odpowiedzialności prawnej, wynikającym z ustawy z dnia 13 kwietnia 2007 r. o zapobieganiu szkodom w środowisku i ich naprawie.

Pracę zamyka „Zakończenie”, będące miejscem na podsumowanie i sformułowanie wniosków.

Recenzowana monografia bardzo dobrze wygląda od strony źródłowej. W wykazie cytowanych prac widnieją 241 pozycje, przy czym są wśród nich wszystkie liczące się prace krajowe, które podejmują problematykę obszarów Natura 2000. Są też dzieła nieprawnicze i trudno nie dostrzec $\mathrm{w}$ wykazie prac autorstwa K. Jaspersa, R. Ingardena oraz A. Smitha. Autor przywołuje także literaturę obcą, opublikowaną $\mathrm{w}$ j. angielskim i niemieckim. W prowadzonych rozważaniach odwołuje się także do orzecznictwa Europejskiego Trybunału Sprawiedliwości, Trybunału Konstytucyjnego i sądów krajowych (przede wszystkim sądów administracyjnych). Liczba powoływanych judykatów sięga pięćdziesięciu (choć brakuje ich odrębnego wykazu).

Podjęta analiza rozwiązań prawnych koncentruje się w aspekcie badawczym wokół koncepcyjnych odrębności obszarów Natura 2000. Autor rozpatruje je na dwóch splatających się płaszczyznach: legislacyjnej oraz doktrynalnej. Z pierwszą związane są pytania następujące: czy odrębność instytucji obszarów Natura 2000 tkwi wyłącznie w fakcie, że ma ona swoje korzenie w prawie europejskim, czy też są argumenty przemawiające za tym, iż jest nowym obliczem prawa ochrony przyrody? Czy wytworzono na jej użytek nowe instrumenty prawne, będące racją 1/2014 na rzecz nowej jakości w prawnej ochronie przyrody? Głównym 
argumentem na rzecz nowej jakości w prawie ochrony przyrody jest przede wszystkim kształt tzw. oceny habitatowej. Autor dostrzega poglądy zgłaszane $\mathrm{w}$ literaturze, w myśl których ocena taka stanowi jedynie modyfikację standardowej oceny oddziaływania, ale ze stanowiskiem takim się nie zgadza. Wskazuje przy tym następujące argumenty: 1) wyraźne rozdzielenie legislacyjne „klasycznej” i tzw. naturowej oceny oddziaływania, 2) odmienne skutki prawne wywierane przez obie kategorie ocen oddziaływania - w zasadzie wiążące w przypadku oceny „naturowej” i tylko pomocnicze w przypadku oceny „klasycznej”, 3) inaczej sformułowany sposób doboru przedsięwzięć do obydwu kategorii ocen - a zwłaszcza brak jasnych i precyzyjnych kryteriów, przesądzających z góry, które przedsięwzięcia należy poddawać ocenie oddziaływania na obszar Natura 2000. Zagadnienie jest dyskusyjne, ale obrona prezentowanego stanowiska wypada przekonująco.

Przy okazji pojawia się pytanie o techniczno-prawną jakość polskich przepisów transponujących regulacje dyrektyw i jednocześnie kreujących prawny obraz Natury 2000 w Polsce. W tym punkcie rozważań konkluzja jest taka, że ustawodawca zbyt pośpiesznie wypełnił obowiązki transpozycyjne, w niewystarczającym stopniu bacząc na skomplikowane relacje regulacji Natury 2000 z zastanym porządkiem prawnym.

Druga płaszczyzna badań, jak się wydaje najciekawsza i najbardziej płodna poznawczo, to ustalenie przystawalności rozwiązań prawodawczych do konstrukcji teoretycznych, wypracowanych przez naukę prawa. Autor przyjmuje założenie, że za procedurami i instrumentami ustawy o ochronie przyrody, które wyraźnie się odróżniają od znanych prawu polskiemu, podążają także swoistości doktrynalne i dąży do ich potwierdzenia (np. formułując potrzebę zredefiniowania pojęcia nadzoru za sprawą udziału w procedurze przed organami krajowymi organów europejskich). Istotną doktrynalnie kwestią prawną jest także ocena charakteru opinii Komisji Europejskiej i sposobu determinowania przez nią rozstrzygnięć wydawanych przez organy krajowe. W nurcie rozważań doktrynalnych mieści się także podjęta próba prawnej kwalifikacji działań podejmowanych przy wyznaczaniu obszarów Natura 2000. Niektóre wątki 
z tego nurtu rozważań mogłyby jednak zostać rozszerzone, zaś stanowisko sformułowane bardziej zdecydowanie. Dla przykładu Autor zastanawia się nad rolą gmin w procesie wyznaczania obszaru Natura 2000, w szczególności w kontekście wzorców konstytucyjnych (art. 5 i 166 Konstytucji). Stawia doniosłe pytanie, czy nie mamy tu do czynienia z zachwianiem proporcji pomiędzy interesem ogólnokrajowym i lokalnym. Rzecz w tym, że uwagi zamykające ten wątek są ogólnikowe. Podobnie jest z oceną charakteru prawnego zgody Rady Ministrów na kształt listy proponowanych obszarów mających znaczenie dla Wspólnoty oraz listy obszarów specjalnej ochrony ptaków (przedstawianej przez ministra właściwego do spraw środowiska).

Pomimo tych nielicznych uwag krytycznych monografię „Obszary Natura 2000 w prawie polskim” należy ocenić wysoko i polecić wszystkim zainteresowanym tą problematyką. 